\title{
Akut ve kronik osteomiyelitin cerrahi tedavisi
}

\section{Surgical treatment of acute and chronic osteomyelitis}

\author{
Mehmet Kocaoğluํㅜ, F. Erkal Bilen² \\ ${ }^{1}$ Orthoteam, Fulya, İstanbul \\ ${ }^{2}$ Maçka EMAR Tıp Merkezi, Şişli, İstanbul
}

\begin{abstract}
Osteomiyelit terimi kemik (osteon), ilik (myelo) ve enfeksiyon (itis) eklerinden oluşmakta; kemik dokusunun mikroorganizmalar ile enfekte edildiğini tanımlamaktadır. Osteomiyelit süresine göre (akut/kronik), patogenezine göre (posttravmatik/hematojen, vb.), lokalizasyonuna göre (omurga, kalça, diz, ayak vb.) ve hastaya göre (yenidoğan/ çocuk/erişkin/immun sistemi zayıf kişiler) olmak üzere çeşitli şekillerde sınıflandırılabilir. Gerek medikal ve gerekse cerrahi tedavi öncesi hasta mutlaka risk faktörleri açısından ayrıntılı olarak değerlendirilmelidir. Nütrisyonel durum, diabetes mellitus, ekstremitenin vasküler yapısı, renal ve/veya hepatik yetmezlik, orak hücreli anemi gibi kan hastalıkları, kronik granülomatöz hastalık açısından ayrıntılı sistem sorgusu ve değerlendirmesi yapılmalıdır. Osteomiyelitin prevansiyonu bakteri insidansının azaltılması, yaraya inokulasyonun önlenmesi şeklinde olmalıdır. Konuya ayrıntılı girmeden önce belirtmek gerekir ki cerrahi tedavi antibiyoterapiye cevap vermeyen olgularda rezerv olarak bırakılmalıdır. Yalnızca abse varlığının ortaya konulmuş olması mutlak cerrahi endikasyon değildir. Özellikle 3 mm'nin altındaki abseler medikal tedaviye iyi cevap verebilmektedir. Osteomiyelitin uygun tedavisi; yeterli drenaj, nekrotik dokuların debridmanı, ölü boşlukların kapatılması, yaranın sağlıklı doku ile örtülmesi ve spesifik antibiyoterapi şeklinde olmalıdır.
\end{abstract}

Anahtar sözcülkler: osteomiyelit; kemik enfeksiyonu; osteomiyelit cerrahisi

\section{"Bacteria are nothing; the environment is everything" J. T. Mader}

\section{AKUT OSTEOMIYELIT}

Akut osteomiyelit ve/veya septik artritin cerrahi tedavisi antibiyoterapi ile birlikte önemlidir. ${ }^{[1-4]}$ Cerrahi tedavi özellikle, etyolojik bakteriyel ajanı belirleme ve uygun antibiyotik seçimi bakımından önemlidir. Ayrıca eklem tutulumu da birlikte olan akut osteomiyelit olgularında yapılan cerrahi drenaj hem intra-artiküler
The term osteomyelitis come from osteon (bone), myelo (marrow) and itis (infection), thus defines infection of bone marrow by microorganisms. Osteomyelitis can be classified according to duration of symptoms (acute/chronic), to underlying pathogenesis (post-traumatic/hematogenic, etc.), to its location (spine/hip/knee/foot, etc.) and to the patient (newborn/child/adult/immuncompromised patients). Before the treatment, either medical or surgical, the patient should be evaluated throughly in terms of possible associated risk factors. During the evaluation, nutritional status, diabetes mellitus, vascular status of the extremity, renal and/or hepatic insufficiency, sickle cell anemia, chronic granulomatous diseases and other factors must be questioned in detail. The prevention of osteomyelitis requires decrease of bacterial incidence and inoculation into the wound. Surgical treatment should be preserved for cases which do not respond antibiotherapy. Detection of an abscess only does not warrant an absolute indication for surgery. Abscesses smaller than $3 \mathrm{~mm}$ especially may respond well to medical treatment. The appropriate treatment for osteomyelitis consists of adequate drainage, debridement of all necrotic tissues, filling of dead spaces, coverage of the wound and specific antibiotherapy.

Key words: osteomyelitis; bone infection; surgery for osteomyelitis

basıncı azaltır ve de kalıcı kıkırdak hasarını önler; sekel kalma yüzdesi azalır. ${ }^{[5]}$

Çok küçük yaştaki çocuk hastalarda sadece septik artrit bulgusu varsa artroskopik drenaj yeterli olur ve hastalığın kemik dokuya atlayarak sekonder akut osteomiyelit gelişmesini önler. ${ }^{[6]}$ Ayrıca kemik nekrozunu önleyerek damarlanmanın azalmasını ve böylece antibiyoterapinin penetrasyonunu artırır. ${ }^{[7]}$ Ancak cerrahi teknik (artrotomi/artroskopi/aspirasyon) halen tartışmalıdır. ${ }^{[8]}$ Biz artroskopik debridmanı tercih etmekteyiz. Bir yaşın üzeri çocuklarda artrotominin aspirasyona

- İletişim adresi: Prof. Dr. Mehmet Kocaoğlu, Hakkı Yeten Cad., No: 19 Kat: 6. Fulya, İstanbul

Tel: 0532 - 2123338 e-posta: drmehmetkocaoglu@gmail.com

- Geliș tarihi: 25 Mayıs $2020 \quad$ Kabul tarihi: 17 Haziran 2020 
üstünlüğü ispatlanmamıştır. ${ }^{[9]}$ Sıklıkla sekonder akut osteomiyelit yaratan yenidoğanın kalça septik artriti mutlaka artrotomi ile drene edilmelidir. ${ }^{[10]}$

Buna karşılık akut ve komplikasyon oluşmamış osteoartiküler enfeksiyonlarda bazen hastayı önce medikal tedavi ile takip etmek, olgunun seyrine göre eğer antibiyoterapiye cevap oluşmamışsa, cerrahi tedavi diğer bir seçenektirr. ${ }^{[11]}$ Buna karşılık metisiline dirençli Staphilococcus aureus (MRSA) veya S.aureus suşlarının ürettiği Panton-Valentine leukocidin (PVL) pozitif ise genellikle cerrahi tedavi ilk seçenek olmalıdır. Zira bu olgular agresif bir seyir izler. ${ }^{[5]}$

Özetlersek, akut (hematojen) osteomiyelitin cerrahi endikasyonları şunlardır:

- Ampirik antibiyoterapiye cevap vermeyen (ateş, lokal enflamasyon, serum reaktif protein (CRP) değerlerinin yükselmesi vb.) olgular

- Özellikle MRSA ve PVL virulanslı suşlarla oluşan periostal abse, derin yumuşak doku absesi ile birlikte seyreden olgular

- Omuz ve kalça eklemlerinin sinus traktı da olan pürülan septik artritle seyreden osteomiyelit olguları ${ }^{[2,12,13]}$

\section{Cerrahi Teknikler}

Akut osteomiyelit tedavisinde cerrahi seçenek ön plana çıkmışsa, hemen daima acil şartlarda yapılmalıdır.

- Eğer cerrahi bir revizyon gerekiyorsa mikrobiyolojik kültür sonuçları çıkana dek beklenmelidir.

- Biyofilm oluşması çok çabuk gerçekleştiğinden eğer implant varsa çıkarılmalıdır.

- Cerrahi işlem sonrası mümkünse VAC (Vacuum Assisted Closure) tedavisi yardımcı olarak planlanmalıdır.

- Kemikteki implantlar çıkarılmadıkça (ya da yenisi ile değiştirilmedikçe) radikal debridman mümkün olmaz.

\section{Fenestrasyon}

Bu teknikte multipl drilleme ve osteotom ile kemiğin biyomekanik olarak az yük aldığı (örneğin femur lateral korteksinden) tek korteksinin pencere olarak açılmasıdır. (Hastanın yaşına göre değişmekle birlikte 3,5-4,5 mm'lik driller ve keskin osteotomlar kullanılmalıdır) Bu pencerenin miktarı sağııkı dokuları görecek kadar fazla ve fakat patolojik kırık yaratmayacak kadar küçük olmalıdır (Şekil 1). Çıkarılan kortikal parça patolojik ve mikrobiyolojik incelemeye yollanmalıdır. Medüller boşlukdan da örnekler alınmalı; daha sonra küretler aracılığı ile kanayan sağlıklı doku görülene kadar debride edilmelidir. Oluşan boşluğa ısıya dayanıklı antibiyotikle karıştııımış polimetil metakrilat (PMMA) tanecikleri yerleştirilerek lokal antibiyotik salınımı sağlanmış olur (Şekil 2-4).

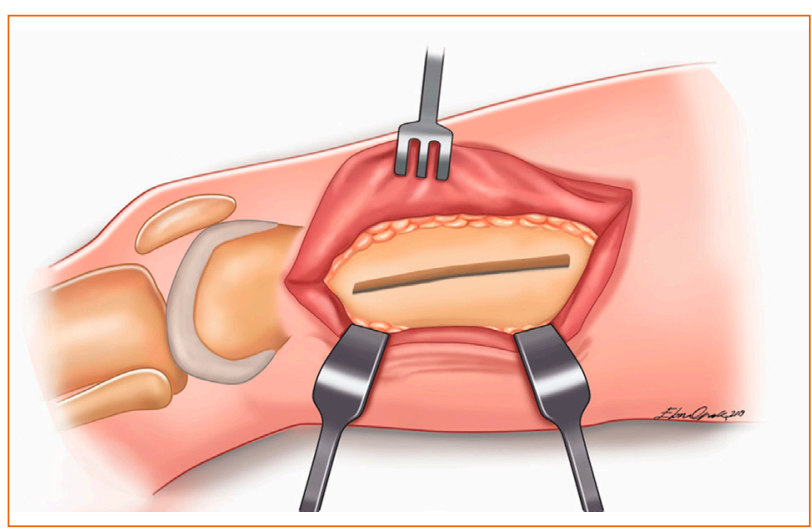

Şekil 1. Femura lateralden uygulanan fenestrasyon.

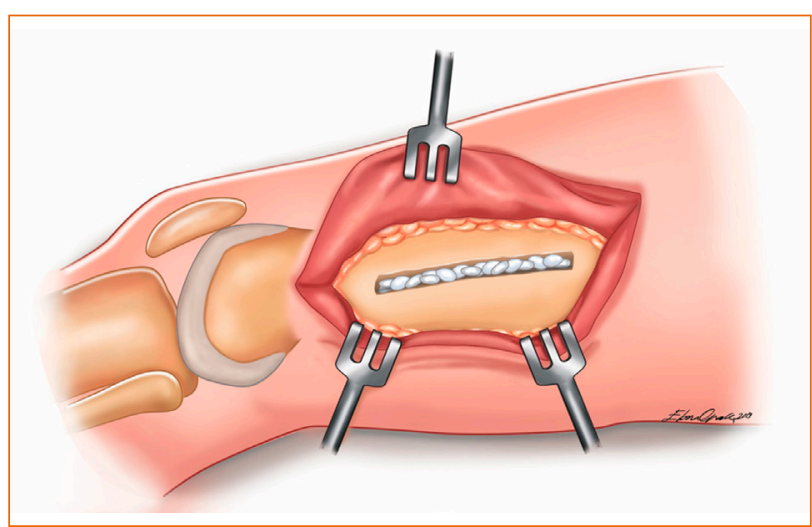

Şekil 2. Femur lateralindeki fenestrasyon bölgesine antibiyotikli çimento taneciklerinin yerleştirilmesi.

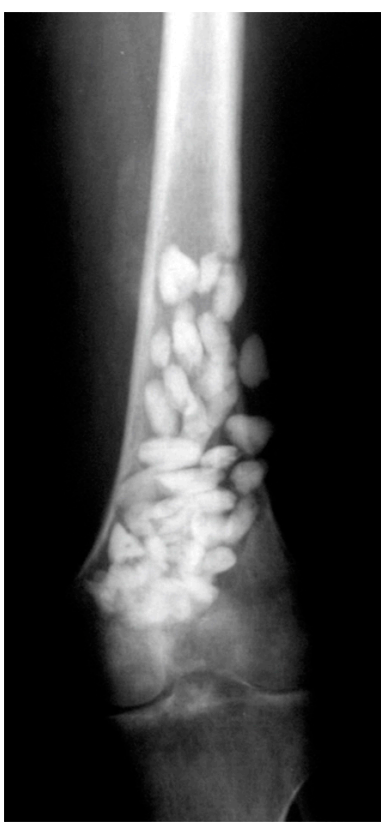

Şekil 3. Femur distal bölgesinde uygulanmış antibiyotikli çimento taneciklerini gösteren anteroposterior grafi.

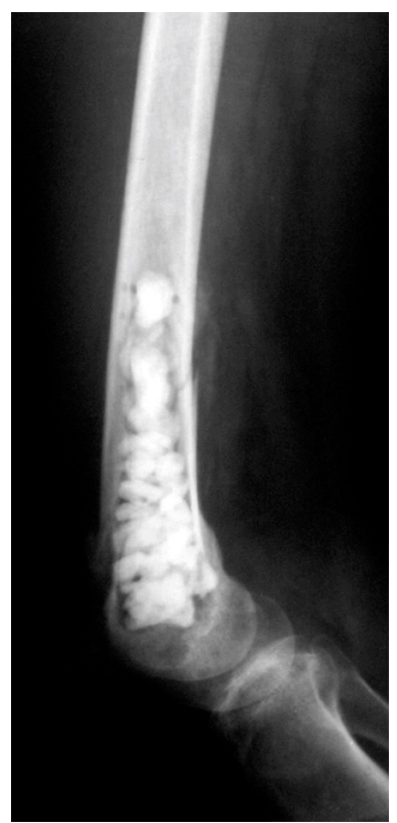

Şekil 4. Femur distal bölgesinde uygulanmış antibiyotikli çimento taneciklerini gösteren lateral grafi. 


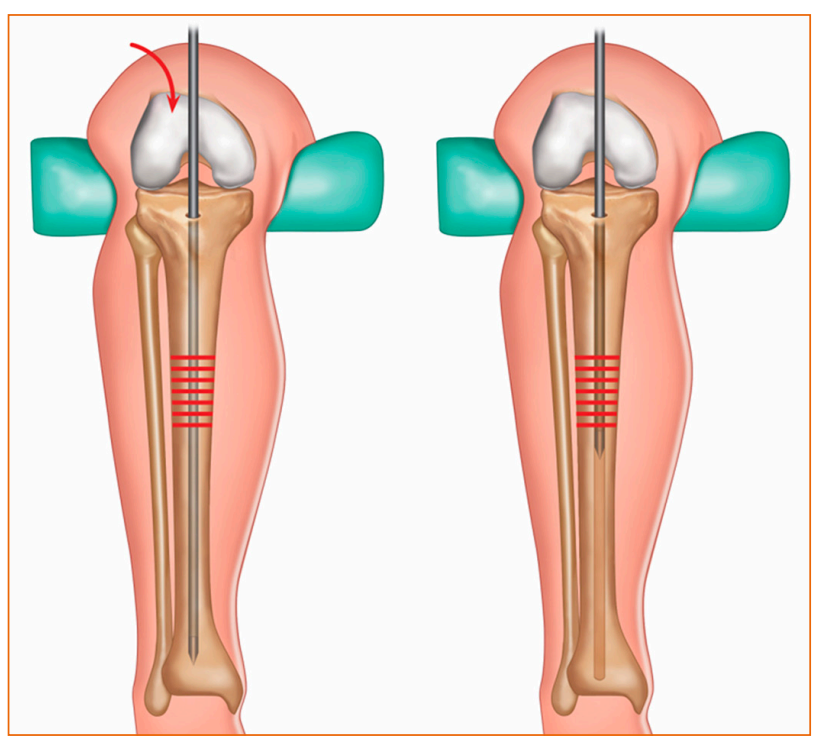

Şekil 5. Femurda diyafizer osteomiyelit olgusunda intramedüller oyma işlemi.

Eğer lezyon enkapsüle ise intramedüller (IM) boşluk retrograd veya antegrad oyulmalıdır. Distal açılmış pencereler için antegrad oyma tercih edilmelidir (kırık riski!). Bilahare jet lavaj ile tüm kanal en az 4-6 litre serum fizyolojik ile irrige edilmelidir.

Distal metafizer bölge enfeksiyonlarında fenestrasyon, yıkama ve sert skleroze kemik varsa burr ile temizleme yeterlidir (intramedüller kanal oyma işlemi tavsiye edilmez). Yara kapatılırken aspiratif dren yerleştirilmelidir.

\section{Sauserizasyon (Papineau Tekniği)}

Özellikle juksta-artiküler uzun kemiklerin lezyonlarında endikedir. Genellikle turnike altında uygulanmalıdır. Enfekte bölge korteksi açılarak debride edilir, mekanik irrigasyonu takiben yara açık bırakılır; bol vazelin ve rivanol emdirilmiş gazlar (ya da Peru balsa$\mathrm{mı}$ ) ile üzeri örtülür. Yeterli sayıda pansumanı takiben enfekte drenaj yoksa ikinci seansta yara üzeri ya yumuşak doku ya da osteokutanöz flep ile örtülmelidir. Bu teknik özellikle dirençli suşlar ve yaşlı hastalarda tercih edilmelidir. Sauserizasyon ayrıca sekestre olan kronik osteomiyelit olgularında da uygulanır. ${ }^{[14]}$

\section{İntramedüller (IM) Oyma (IM Reaming)}

Özellikle uzun kemiklerin diyafizer tutulumlu enfeksiyonlarında endikedir. Metafizer lezyonlarda fenestrasyon tercih edilmelidir. Mevcut iM çivi çıkarılmalı; çıkarılırken cilt ve ciltaltı dokuların kontamine edilmemesi açısından yumuşak doku koruyucu ekipman da kullanılmalıdır (Şekil 5). Ayrıca kanaldan drenajı sağlamak için medüller kanalın en alt noktasına 6 mm'lik drille drenaj deliği açılmalıdır. Bu delikten bir adet aspiratif dren yerleştirilmelidir. Çıkarılan IM çivinin çapından 1,5 $\mathrm{mm}$ daha fazla tekrar oyulmalıdır. Bu arada ısı nekrozunu önlemek için kanal içi soğuk serum fizyolojik ile irrige edilmelidir. Kanalın oyulma işleminden sonra firça ile kanal içi mekanik temizlik yapılmalı basınçlı serum fizyolojik ile yıkanmalıdır. En son kanal içine gentamisin emdirilmiş spongostanlar (ya da gentamisin emdirilmiş zincirler) yerleştirilerek yara kapatılmalıdır. Eğer zincir yerleştirilmişse ortalama üç hafta içinde gentamisin içeriği salınarak etken madde kalmadığı için zincir tanelerinin üzerinde biyofilm oluşabilir; onun için ameliyat sonrası 3. haftada çıkarılmalıdır.

Oyma işlemi sonrası instabilite (patolojik kırık riski) düşünülüyorsa alçı, plastik breys ya da eksternal fiksatör ile kemik korumaya alınmalıdır. Ayrıca antibiyotik karıştııılmış çimento ile oluşturulan geçici iM çivi de kanal içine yerleştirilebilir. ${ }^{[3,14]}$

\section{KRONIK OSTEOMYELIT}

Kemik enfeksiyonunu takiben iki hafta kadar sonra ortaya çıkan akut osteomiyelitten farklı olarak kronik osteomiyelit altı hafta ya da daha sonrasında ortaya çıkmaktadır. Kronik osteomiyelitteki patojenlerin oluşturduğu ilerleyici enflamatuar süreç nedeniyle kemik destrüksiyonu ve sekestir oluşumu gelişmektedir.

Klinik olarak akut osteomiyelite göre daha sessiz seyretmekle birlikte ölü kemik oluşumu, tedavi sonrası nüks olabilmesi ve rekonstrüktif cerrahi girişimler gerektirmesi nedeniyle oldukça zor bir tedavi süreci gerektirmektedir.

Predispozan faktörlerin başında travma, açık kırıklar ve cerrahi öyküsü gelmektedir. Bunun yanında diyabet, periferik damar hastalığı, malnütrisyon, hipotansiyon, kronik kortikosteroid kullanımı, malignite, aşıı alkol kullanımı, tütün kullanımı, sistemik veya lokal bağışıklığın bozulması gibi ek nedenler de kronik osteomiyelit gelişimini kolaylaştırmaktadır. ${ }^{[15-18]}$

\section{Tedavi}

Tedavi semptomların süresi ve şiddetinin yanı sıra hastanın mevcut komorbiditelerine bağlı olarak düzenlenmelidir. Sıklıkla kronik osteomiyelit bölgesini çevreleyen yumuşak doku örtüsü ve vaskülarizasyonu da bozulmuştur. Tedavideki ana amaç enfekte ve ölü dokunun tamamının eksizyonu ve sonrasında oluşan ölü boşluğun da telafi edileceği bir cerrahi rekonstrüksiyon yapılmasıdır. Bu oldukça meşakkatli ve zor bir süreç olup bu konuda tecrübeli merkezlerce yapılması tercih edilmelidir. 

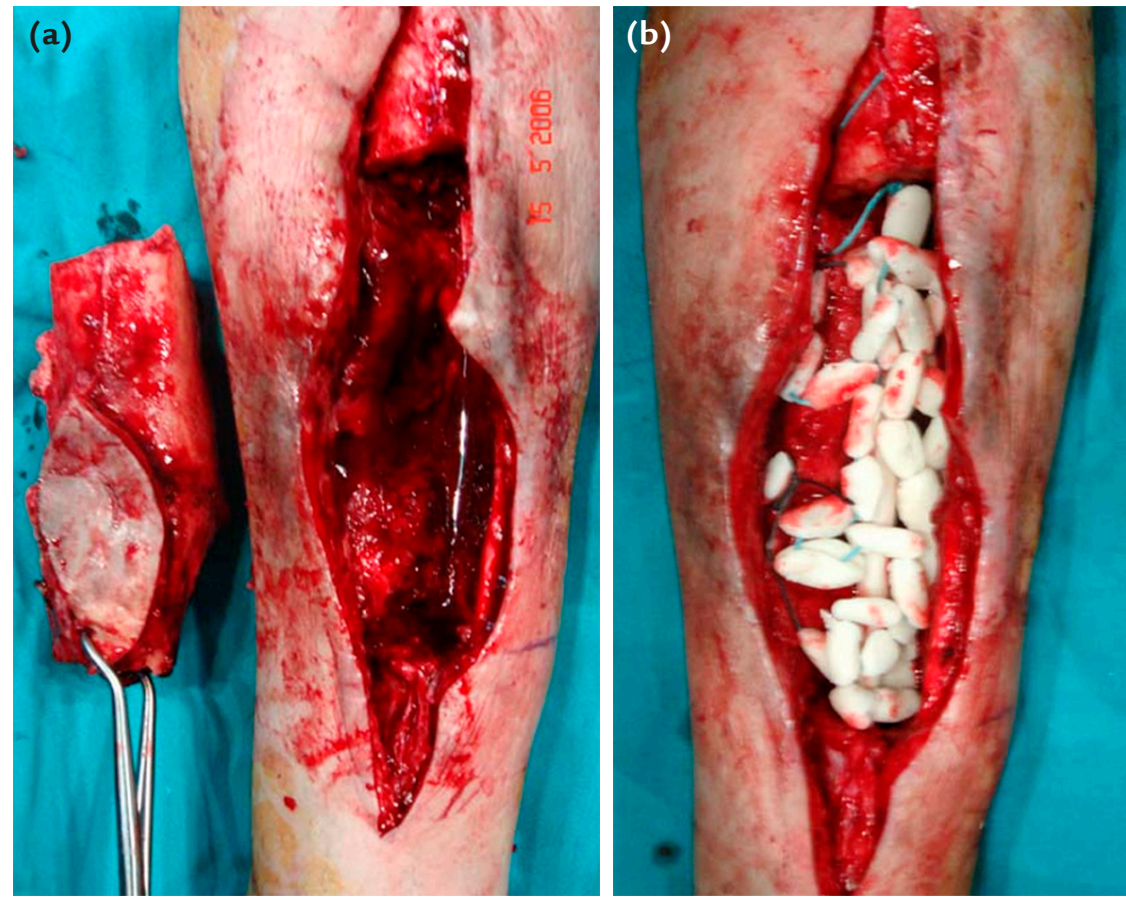

Şekil 6. a, b. Ölü dokuların debride edilerek uzaklaştırılması (a). Oluşan ölü boşluğun antibiyotikli çimento taneciklerinden oluşan zincirle doldurulması (b).

Sonuç olarak tedavideki hedef şu dört faktörün sağlanması olmalıdır:

1. Enfeksiyonun gerek lokal, gerekse sistemik olarak eradike edilmesi

2. Dizilimi normal stabil ekstremite elde edilmesi

3. Normal kas işlevi sağlanması

4. Normal eklem işlevi kazanılması

Bu amaçlara ulaşabilmek genellikle aşamalı bir tedavi protokolü ile sağlanabilmektedir. Bu tedavi ideal olarak bir ortopedi ve travmatoloji uzmanı, bir enfeksiyon hastalıkları uzmanı, bir plastik cerrah ve/veya mikrovasküler cerrahide tecrübeli bir damar cerrahı ve mümkünse hiperbarik oksijen tedavisinde tecrübeli bir hekimden oluşan multidisipliner bir ekipten oluşmalıdır.

\section{Debridman}

Ölü dokunun (kemik, yumuşak doku ve cilt) tam olarak eksize edilip uzaklaştırılması gereklidir (Şekil 6). Fistül mevcutsa ameliyat esnasında fistül ağzından enjektörle metilen mavisi gönderilerek enfekte bölgenin işaretlenmesi cerrahi bölgenin identifiye edilmesini kolaylaştııı. Debridmana canlı kemik kenar elde edilene kadar devam edilmelidir (sağlıklı, kanayan kemik yüzeyi görülmesi=paprika bulgusu). Eğer debridman yüksek hızlı burr ile yapılıyorsa ısınmanın getireceği nekroz riski sürekli soğuk irrigasyon uygulanarak elimine edilmelidir.
Uzaklaştırılan ölü doku ve sıvıdan bakteriyel, fungal ve granülomatöz enfeksiyonlar için kültür örnekleri gönderilmelidir. Debridmanı takiben bol steril mayi ile irrigasyon yapılmalıdır. Son irrigasyon mayiine antibiyotik eklenebilir. Debridman ve irrigasyon tamamlandıktan sonra eldivenler, steril örtü, enstrümanlar ve diğer gereçler kontamine kabul edilerek sterilleriyle değiştirildikten sonra bir sonraki aşamaya geçilmelidir.

\section{Ölü Boşluk Varsa Ne Yapılmalı?}

Radikal olarak yapılan debridman sonrası genellikle ölü boşluk olarak adlandırılan alanlar oluşabilmektedir. Bu bölgede damarlanma olmadığı ve kolaylıkla seröz ya da pürülan mayi birikerek patojenlerin üremesine uygun bir ortam oluşabileceği için antibiyotik emdirilmiş çimento ile doldurulması gereklidir. Eğer yumuşak doku örtüsü sağlanamıyorsa yarı geçirgen bir membran uygulanarak çimentodan salınan antibiyotiğin bölgede kalması sağlanmalıdır.

\section{Enfekte Bölgede İmplant Varsa Ne Yapılmalı?}

Enfekte bölgede mevcut olan implantın çıkarılıp çıkarılmaması gerekliliğine dair karar olguya özgü olarak verilmelidir. Bu karar implantın uygulandığı zamandan beri geçen süre, kemik iyileşmesinin derecesi, implantın sağladığı stabilite katkısı ve uygulandığı konuma göre farklılık göstrebilir. 


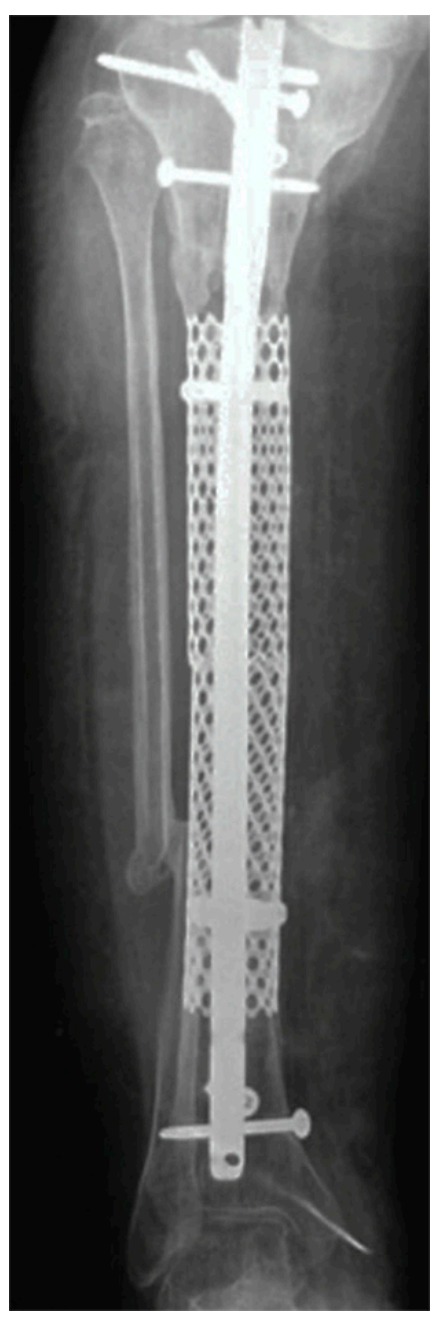

Şekil 7. Radikal debridman sonrasında oluşan uzun tibia defektinin titanyum kafesle doldurularak greftlenmesi.
Saint Antonio TX ABD) yara bölgesindeki aşırı sıvı birikimi önlenirken, hücre proliferasyonunda belirgin bir artış sağlanması ve granülasyon dokusu oluşturulmasıdır. Bu yöntem ayrıca yara kenarlarına hafif bir germe uygulayarak dolaşımını bozmadan yaranın küçülmesine de katkıda bulunmaktadır. Böylelikle daha küçük boyutlu bir rekonstrüksiyon prosedürü yeterli olabilmektedir.

Radikal debridman ve yerine göre uygulanan vakumlu pansuman sonrası geride kalan defektin boyutuna göre yapılacak olan rekonstrüksiyona karar verilmelidir. Burada karar şu kriterlere göre verilmelidir ${ }^{[19]}$ :

- Osteosentezin tipi

- Yumuşak doku defektinin yeri ve boyutu

- Lokal vasküler dolaşımın durumu

- Hastanın uyumu

\section{Hiperbarik Oksijen Tedavisi}

Özellikle sistemik antibiyoterapi gereken ve enfeksiyonda alevlenme saptanan olgularda $30-40$ seans uygulanması özellikle ağır tütün kullanıcı, bölgesel radyoterapiye bağlı dolaşım bozukluğu olan hastalarda tercih edilebilir.

\section{Titanyum Kafes Uygulaması}

Enfekte bölgenin radikal debridmanı sonrası $10 \mathrm{~cm}$ 'yi aşan defekt varlığında kullanılabilen diğer bir yöntem de titanyum kafes ve greftleme yöntemidir (Şekil 7). Burada sağlıklı bir yumuşak doku örtüsü varlığı gereklidir. Bilgisayarlı tomografi ile kafes içindeki kemik oluşumu takip edilebilir. Ancak tekrar enfeksiyon gelişebileceği ve eksternal tespit yöntemleri ile rekonstrüksiyon gerekebileceği göz önünde bulundurulmalıdır.

\section{Eksternal Tespit Yöntemleri}

çkartılması en doğru karar olacaktır. Eğer kırık kaynamadı ve implant stabiliteyi sağlıyorsa implantın yerinde kalması daha doğru olur. Ancak, kaynama olmamış ve implant stabiliteye katkıda bulunmuyorsa çıkarılmalıdır. Bu durumda stabilite başka bir cihazla, tercihan bir eksternal fiksatörle sağlanmalıdır.

\section{Yumuşak Doku Örtüsü}

Yeterli yumuşak doku örtüsü bulunan olgularda enfeksiyonun boyutuna göre yaranın primer ya da gecikmeli olarak kapatılmasına karar verilir. Eğer yumuşak doku örtüsü bozulmuşsa lokal ya da serbest kas flepleri uygulanmalıdır.

Diğer bir yöntem de negatif basınçlı yara örtüm teknikleri kullanılarak (vakumlu yara örtümü, VAC, $\mathrm{KCI}$

\section{Bifokal yöntem: akut kısaltma ve tedrici uzatma}

Kemik kaybı olan olgularda defekt akut kısaltma ile kapatılıp, sonrasında sağlıklı bölgeden yapılan osteotomi bölgesinden uzatma uygulanarak kemik orijinal boyuna tedricen getirilebilir. ${ }^{[20]}$ Bizim tecrübemize göre akut kısaltmada güvenli sınır tibiada $4 \mathrm{~cm}$ iken, femurda 6-7 cm civarında olmaktadır. Eğer bu değerler defektin kapatılması için yeterli olmadıysa defekt günde $2 \mathrm{~mm}$ hızla tedricen kapatılmalıdır. Cerrahi esnasında ayak arter nabızları, Doppler ultrason değerlendirmesi, kapiller dolum zamanı ve başparmaktaki oksijen satürasyonu ile ekstremite dolaşımı takip edilebilir. Eğer bu parametrelerde bozulma saptanırsa, distraksiyon normal dolaşım sağlanana kadar geri alınmalıdır (Şekil 8). 

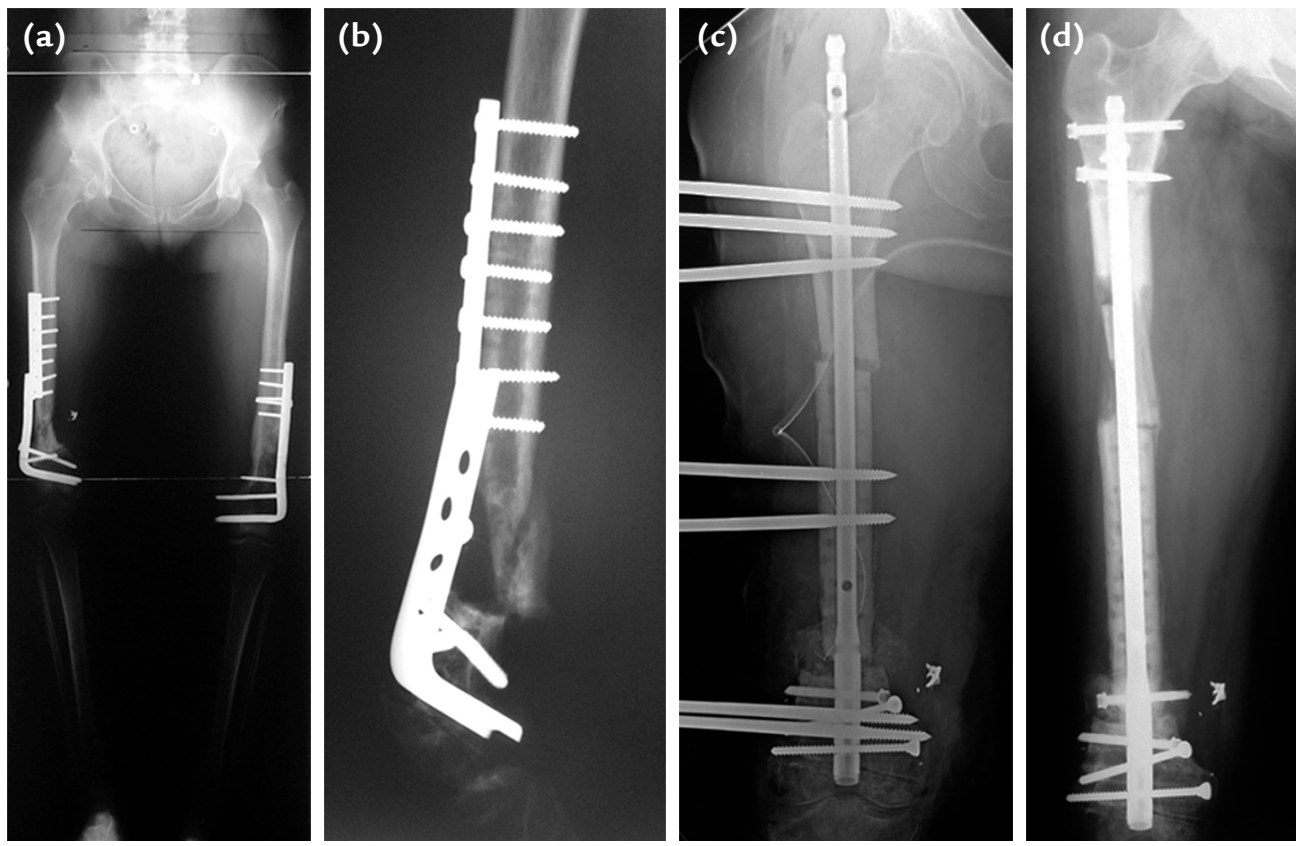

Şekil 8. a-d. Sağ femurda kısalık ve deformiteye yol açan olgunun anteroposterior ortoröntgenogramı (a). Aynı olgunun enfektif ve kaynamamış bölgeyi gösteren distal femur lateral grafisi (b). Enfektif bölgenin radikal debridmanı sonrası akut kısaltma uygulanması (proksimalden yapılan uzatma osteotomisine dikkat ediniz) (c). Proksimal osteotomi bölgesinden yapılan çivi üzerinden uzatma sonrası proksimal kilitlemeyi gösteren grafi (d).
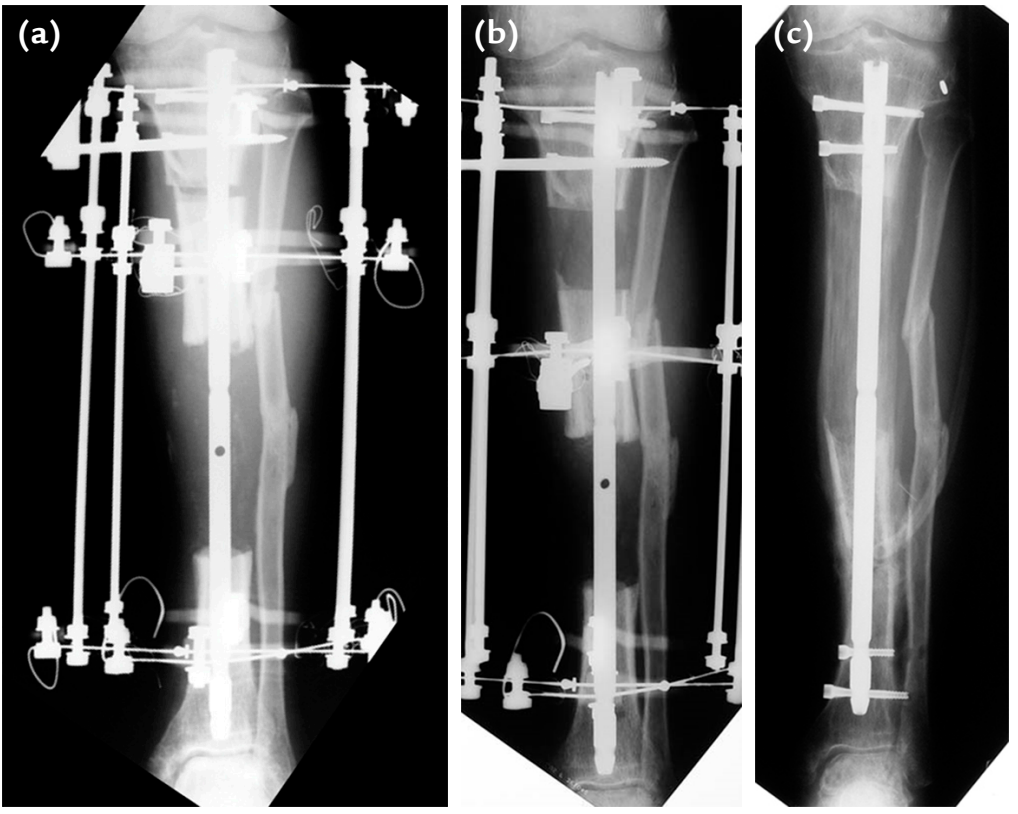

Şekil 9. a-c. Tibiada çivi üzerinden kemik transportu yapılan olgu. Distalde defektif bölge görülmekte, proksimalde osteotomi yapılarak orta segment distale doğru kaydırılacak (a). Orta segmentin kaydırma sürecindeki grafisi (b). Orta segmentin distale kaydırımasını takiben kaynama tamamlandıktan sonraki grafi (c).

\section{Kombine teknikler}

Tıptaki gelişmeler tedavi süresinde kısalma ve hasta konforunda da belirgin artış sağlamaktadır. Kombine teknikler eksternal ve internal tespitin (intramedüller çivi, plak) avantajlarını birleştirerek eskternal tespit süresini neredeyse yarı yarıya azaltabilmektedir. Böylelikle hastanın konforu artmakta, eksternal tespite bağlı komplikasyon oranı azalmaktadır (pin dibi enfeksiyonu, eklem kontraktürü vb.). Eksternal fiksatörün çıkarılmasını takiben bölgede kalan internal tespit materyali stabiliteyi sağlamakta, refraktür ve deformitede nüks gibi problemleri önlemekte ve rehabilitasyonu belirgin ölçüde hızlandırmaktadır.

Kemik transportu için üç yöntem bulunmaktadır (Şekil 9):

- Internal kemik transportu

- Eksternal kemik transportu

- Çivi üzerinden kemik transportu 
Eksternal fiksatör kullanılarak yapılan kemik transportunun başarılı sonuçlar verdiği gösterilmiştir. Eksternal tespit süresi, gereken distraksiyonun uzunluğu ile orantılı olmakta ve bu süre eksternal tespite özgü komplikasyon riski taşımaktadır. Distraksiyon evresi tamamlandığında, bunun yaklaşık iki katı süren konsolidasyon evresi başlamakta ve hasta için tolere edilmesi güç bir süreç yaşanmaktadır. Eksternal fiksatörün konsolidasyon tamamlanmadan çıkartılması ise refraktür, deformite gelişimi ve kısalma gibi komplikasyonlara neden olabilmektedir. Ayrıca eski usulde uygulanan eksternal tespit düzenekleri dizilim problemi gelişmesi nedeniyle sıklıkla tekrar tekrar ince ayar gerektirebilmektedir. Eksternal fiksatörün intramedüller çivi ile kombine kullanılması dizilim problemi gelişmesini önlemekte, eksternal tespit süresini belirgin olarak kısaltmaktadır (eksternal fiksatör sadece distraksiyon döneminde kullanılıp, konsolidasyon fazında intramedüller çivi kilitlenip stabiliteyi sağladığı için eksternal fiksatöre ihtiyaç kalmamaktadır).

Alternatif olarak benzer avantajlar intramedüller çivi yerine plak kullanılarak da sağlanabilimektedir. Veya kemik transportu tam motorize intramedüller çiviler yardımıyla da sağlanabilmektedir (internal uzatma çivileri).

Biz, 5-12 cm arası defektlerde çivi üzerinden kemik transportu yöntemini tercih ediyoruz. Ancak, vasküler hastalık, diabetes mellitus ve aktif enfeksiyon varlığında bu yöntemin kontrendike olduğu unutulmamalıdır. Bu yöntem için $12 \mathrm{~cm}$ üzeri defekt varlığı ve tütün kullanımı göreceli kontrendikasyon oluşturmaktadır. ${ }^{[21]}$

\section{KAYNAKLAR}

1. Mader JT, Calhoun JH, Lazzarini L. Adult Long Bone Osteomyelitis (Chap 6). In: Mader JT, Calhoun JH, editors. Musculoskeletal Infections. New York, NY: Marcel Dekker; 2003. p. 149-182.

2. Dartnell J, Ramachandran $M$, Katchburian $M$. Haematogenous acute and subacute paediatric osteomyelitis: A systematic review of the literature. J Bone Joint Surg $\mathrm{Br}$ 2012;94-B(5):584-95. Crossref

3. Saavedra-Lozano J, Falup-Pecurariu O, Faust SN, Girschick $H$, Hartwig N, Kaplan S, Lorrot M, Mantadakis E, Peltola H, Rojo P, Zaoutis T, LeMair A. ESPID (European Society for Paediatric Infectious Diseases) Clinical Practice Guideline. Bone and Joint Infections. The Pediatr Infect Dis J 2017;36(8):78899. https://journals.Iww.com/pidj/Documents/Aug\%20 2017\%20ESPID\%20Bone_and_Joint_Infections.pdf
4. Pääkkönen $M$, Peltola $H$. Simplifying the treatment of acute bacterial bone and joint infections in children. Expert Rev Anti Infect Ther 2011;9(12):1125-31. Crossref

5. Pääkkönen $M$, Peltola $H$. Management of a child with suspected acute septic arthritis. Arch Dis Child 2012;97(3):287-92. Crossref

6. Castellazzi L, Mantero M, Esposito S. Update on the Management of Pediatric Acute Osteomyelitis and Septic Arthritis. Int J Mol Sci 2016;17(6):855. Crossref

7. Thompson RM, Gourineni P. Arthroscopic treatment of septic arthritis in very young children. J Pediatr Orthop 2015;37(1):e53-7. Crossref

8. Hoffer FA, Emans J. Percutaneous drainage of subperiosteal abscess: a potential treatment for osteomyelitis. Pediatr Radiol 1996;26(12):879-81. Crossref

9. Smith SP, Thyoka M, Lavy CBD, Pitani A. Septic arthritis of the shoulder in children in Malawi: A randomised, prospective study of aspiration versus arthrotomy and washout. J Bone Joint Surg Br 2002;84-B(8):1167-72. Crossref

10. Bruce CE, Rowland DJ, Katchburian M, Dartnell J, Robb JE. British Society for Children's Orthopaedic Surgery. The management of acute bone and joint infection in childhood -a guide to good practice; 2016. http://bscos.org.uk/ resources/Downloads/Blue-Book-Infection.pdf

11. Agarwal A, Aggarwal AN. Bone and joint infections in children: Acute hematogenous osteomyelitis. Indian J Pediatr 2016;83(8):817-24. Crossref

12. Kaplan SL. Recent lessons for the management of bone and joint infections. J Infect 2014;68(Suppl 1):S51-6. Crossref

13. Dohin B, Gillet $Y$, Kohler R, Lina G, Vandenesch F, Vanhems $P$, Floret D, Etienne J. Pediatric bone and joint infections caused by Panton-Valentine leukocidin-positive Staphylococcus aureus. Pediatr Infect Dis J 2007;26(11):1042-8. Crossref

14. Hogan A, Heppert VG, Suda AJ. Osteomyelitis. Arch Orthop Trauma Surg 2013;133(9):1183-96. Crossref

15. Panteli M, Giannoudis PV. Chronic osteomyelitis: what the surgeon needs to know. EFORT Open Rev 2016;1(5):128-35. Crossref

16. Papineau LJ, Alfageme A, Dalcourt JP, Pilon L. Chronic osteomyelitis. Open excision and grafting after saucerization. Int Orthop 1979;3(3):165-76. Crossref

17. Tetsworth K, Cierny 3rd G. Osteomyelitis debridement techniques. Clin Orthop Relat Res 1999;360:87-96. Crossref

18. Cierny 3rd G, Mader JT, Penninck JJ. A clinical staging system for adult osteomyelitis. Clin Orthop Relat Res 2003;(414):724. Crossref

19. Heppert V, Glatzel U, Wentzensen A. Postoperative und bakterielle osteitis. Orthopaede 2004;33:316-26. Crossref

20. Şen C, Eralp L, Güneş T, Erdem M, Özden VE, Kocaoğlu M. An alternative method for the treatment of nonunion of the tibia with bone loss. J Bone Joint Surg Br 2006;88-B(6):7839. Crossref

21. Kocaoğlu M, Eralp IL, Bilen FE. Nonunion and Osteomyelitis Following Fractures. In: Wolfson N, Lerner A, Roshal L, editors. Orthopedics in Disasters. Orthopedic Injuries in Natural Disasters and Mass Casualty Events. Berlin Heidelberg: Springer Verlag; 2016. p. 411-36. Crossref 